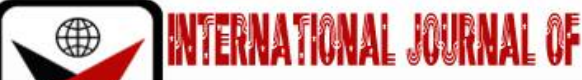

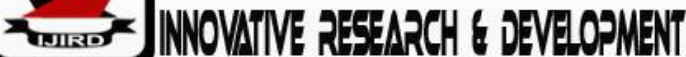

ISSN 2278-0211 (Online)

\section{The effect of District General Assembly on the performance of National Council of Persons with Disabilities in Rwanda}

\author{
Ndayisaba Emmanuel \\ Student, School of Business Studies, \\ Jomo Kenyatta University of Agriculture and Technology, Kenya \\ Mulyungi Patrick \\ Lecturer, School of Business Studies, \\ Jomo Kenyatta University of Agriculture and Technology, Nairobi, Kenya
}

\begin{abstract}
:
The purpose of this study was to investigate the effect of District General Assembly on the performance of National Council of Persons with Disabilities in Rwanda. The study adopted a cross-sectional survey using both quantitative and qualitative approaches. The target population included 8,490 enlisted people with Disabilities in Rwanda from which a 138 respondents were obtained using Glenn's model. A closed ended questionnaire was used to obtain data from the respondents. The data was subsequently analysed using Statistical Package for Social Sciences (SPSS, Version 25.0.0.0). Results showed that cumulatively $77.25 \%$ of the respondents did not concur that the structure affects the hierarchical development, while $22.75 \%$ agreed that structure affects the hierarchical development. Further, the respondents affirmed the inexistence of more noteworthy profitability, more prominent usage of assets or increment of proficiency. I addition the majority differed on the effect of structure on hierarchical adequacy. Similarly, a majority did not agree that authoritative structure affects hierarchical viability. In line with the findings the study concluded that National Council of Persons with Disabilities to a great extent relies upon its structure as it fundamentally influences authoritative execution, development, viability and creativity goals. Moreover the study conclude that when a reasonable hierarchical structure exists, representatives perform better, duties are well-ascribed and execution increments and that a well-planned structure is a precondition for long haul execution. On the basis of the findings the study recommends that administration ought to basically break down the adequacy and productivity of the authoritative structure as a significant indicator of execution. Appropriate structures ought to be taken care of set up to accomplish set objectives and goals; and non-performing associations ought to upgrade their structures so as to achieve the normal execution.
\end{abstract}

Keywords: Structure, performance, strategies, persons with disabilities

\section{Introduction}

Strategic organizational structure across the world has attracted many researchers and created debate among organizational managers and academic world. Managers who intend to design organizational structure usually face difficult decisions as they must choose among a big number of tasks and departments. The first decision focuses on individual jobs, the next two decisions focus on departments or groups of jobs, and the fourth decision considers the issue of delegation of authority throughout the structure (Al- Qatawneh, 2014). Zheng et al. (2010) consider an organizational structure as a tool used for control mechanism to affect employee work outcomes, to ensure that the required tasks are performed effectively and efficiently, and to assist the attainment of organizational goals and objectives. It describes the internal characteristics of an organization which receive attention since they are critical to organizational failure and success, and one of these is organizational performance. According to (Teixeira et al.,2012), organizational structure determines the pattern of communication as well as the formal lines of interaction between individuals within organisations. A good structure does not by itself produce an expected performance. Poor organizational structure aids poor performance irrespective of the ability of the manager. It restricts individual growth, self-fulfilmentand psychological health of the workforceresulting in failure, frustrations and conflict which hinders organizational growth and development (Daft et al., 2010). There is a relationship between organizational structure and job satisfaction because the organizational structure affects employee job satisfaction which in turn affects the productivity (Olajide, 2015). Therefore, the extent to which an organizational structure reduces ambiguity for an employee and clarifies problems such as what the employee is supposed to do, how the employee is supposed to do it, who the employee reports to, who the employee should meet in the event of problems; in all affects their attitudes to work and equally motivates employees to higher performance. Some researchers opine that organizational structure has a positive relationship with organizational performance and others like Awino (2015), 
Diego and Juan (2013) reported negative relationship. However, it is important to know that organizational structure is a formal system of task and reporting relationships that control, coordinates and motivates employees so that they cooperate and work together to achieve organizational goals (Esra and Ozgur, 2014). Just what is organizational structure? It is how job tasks are formally divided, grouped, and coordinated within an organization. When managers develop or change the structure, they are engaged in organizational design, a process that involves decisions about six key elements including work specialization, departmentalization, chain of command, span of control, centralization and decentralization, and formalization (Teixeira et al., 2012). Organizational performance, on the other hand, is an indicator which measures how well an enterprise achieves its objectives (Jones, 2013). Organizational performance can be assessed by an organization's efficiency and effectiveness of goal achievement. Organizational performance comprises the actual output or results of an organization as measured against its inputs (Nwachukwu,2012). Organizational performance measures allow companies focus attention on areas that need improvement by assessing how well work is done in terms of cost, quality and time (Ringim et al., 2012). According to Heilman \& Kennedy-Philips (2011) and (Agbim, 2013), organizational performance is measured on three dimensions: organizational growth, organizational effectiveness, and organizational innovativeness. The major managers and scholars' challenge, therefore, is finding General Assembly enhancing optimal performance of NCPD.

\subsection{Statement of the Problem}

Previous studies argue that, there are six signs of poor organizational structure in local organizations including: low productivity, unequal workload, unclear lines of communication, lack of teamwork, slow decision making, and lack of innovation (Nedal et al., (2013). Unfortunately no empirical evidence is available on the effect of District General Assembly Structure on performance of NCPD in Rwanda. Over the years NCPD has not been able to achieve its objectives through strategic implementation (Gupta, 2015). The question in mind is could this anomaly be associated with inappropriate structure?

\section{Literature Review}

The United Nations Conventions on the Rights of Persons with Disabilities, 2016 in its - Preamble, Considering that persons with disabilities should have the opportunity to be actively involved in decision-making processes about policies and programmes, including those directly concerning them, and in its article 34, States Parties shall, in accordance with their legal and administrative systems, maintain, strengthen, designate or establish within the State Party, a framework, including one or more independent mechanisms, as appropriate, to promote, protect and monitor implementation of the present Convention. When designating or establishing such a mechanism, States Parties shall take into account the principles relating to the status and functioning of national institutions for protection and promotion of human rights.

To comply with UNCRPD, Rwanda created the National Council of Persons with Disabilities by article 139 of the Constitution, Official Gazette $n^{\circ}$ Special of 24/12/2015, entrusted with the responsibility to help in resolving important issues facing the country in disability area.

The NCPD is a public institution created by the law no 03/2011 of 10/02/2011, Official Gazette ${ }^{\circ}$ Special of 10/02/2011, composed by all persons with disabilities with 3 organs: General Assembly, Executive Committees from cell to national level, through organized vote and a National Executive Secretariat responsible for the daily management which is linked to the Ministry of Local Government (MINALOC).

\subsection{Conceptual Framework}

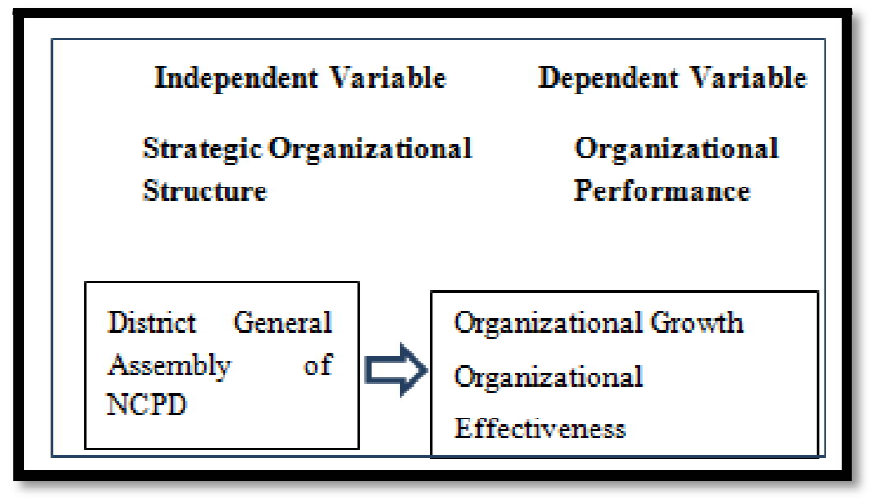

Figurer 1: Conceptual Framework

\subsection{Strategic Organizational Structure}

Strategic organizational structure fills in specific features of how work is organized and coordinated, the way work actually gets done within the organization. It provides the basic architecture that dictates how the organization pursues its strategic objectives (Wyman, 1998).

Organizational structure defines how people are organized or how their jobs are divided and coordinated. It is the formal configuration between individuals and groups concerning the responsibilities, allocation of tasks, and authority in the organization (Greenberg, 2011). Organizational structure includes the nature of formalization, layers of hierarchy, level of 
horizontal integration, centralization of authority and patterns of communication. It is the manner in which power and responsibilities are allocated, and work procedures are done, among members of the organization (Long et al., 2012).

Tran and Tian (2013) define a structure in one sense as the arrangement of duties for the work to be done and this is best represented by the organization chart. They also define a structure as the architecture of business competence, leadership, talent, functional relationships and arrangement. Furthermore, Sablynski (2012) defines the organizational structure as how job tasks are formally divided, grouped, and coordinated.

Organization structure indicates an enduring configuration of tasks and activities. Organizational structure directs the competence of work, the enthusiasm of employees and coordination among the top management and subordinates for a flow of plans and goals in the organization to sketch the future plans. It is a way responsibility and power are allocated, and work procedures are carried out, among organizational members. The most important components of the organizational structure include formalization, centralization, and control (Zheng et al., 2010). Organization structure affects the way in which people at work are organized and coordinated. It equally affects the nature of the relationships they develop, their feelings about these aspects, the ways in which they carry out their works, the attributes required of those who work in particular types of structure and it has implications for the management of the employees' performance. The relationship between structure and performance, however, is more tenuous and is mediated by many other organizational constructs (Teixeira et al., 2012). They discussed formal organizational structures under three dimensions: centralization, formalization and complexity. These studies considered the dimensions proposed by Daft et al. (2010) and then further the discussion by grouping the proposed six dimensions into the three dimensions. Both considered centralization and formalization as dimensions under organizational structures.

\section{Methodology}

The study adopted a cross-sectional study using both quantitative and qualitative methods. Cross-sectional studies involve data collected at a defined time (Olsen et al., 2010). The study measured the outcome and the exposures of participants at the same time. Quantitative method was used to test the relationships between variables using numbers. Qualitative method described human experiences which needed in-depth interviews (Peersman, 2014).

The target population comprised of 8,490registeredpersons with disabilities in Kigali City. Data from EICV3 show that the proportion of households headed by persons with disabilities has raised from 8 to $10 \%$ (6,900 households) and the distribution of these is even across all provinces (NISR, 2012).

The study used Glenn model (2013) to determine sample size:

$$
n=\left[z^{2} \times \frac{(p x q)}{d^{2}}\right]
$$

Where: $\mathrm{n}=$ sample size $\mathrm{z}=$ linked to $95 \%$ confidence interval (use 1.96) $\mathrm{p}=$ expected prevalence of persons with disabilities in Rwanda (10\%) $=0.10$ (NISR, 2012) $q=1-p$ (expected non-prevalence): $1-0.10=0.90 \mathrm{~d}=$ relative desired precision $(5 \%)=0.05$ It is the level of precision, sometimes called sampling error, the range in which the true value of the population is estimated to be).

$\mathrm{n}=3.8416 \times \frac{0.09}{0.0025}=138$ Respondents

$$
n=\left[1.96^{2} \times \frac{(0.10 \times 0.90)}{0.05^{2}}\right]
$$

Thus, sample size $n=138$ persons with disabilities, active members during the study period. As for the qualitative method, a focus group comprising ten (10) persons withdisabilities were selected and interviewed under the guidance of the researcher as a facilitator. Focus group discussion (FGD) was used to increase the depth of the enquiry and revealed all aspects of the phenomenon (Peersman, 2014). Probability sampling technique was used, whereby participants were accessed on the basis of their availability at the NCPD national office (Gasabo District). Purposive sampling technique (also called judgment sampling), a non-probability sampling, was used to select the focus group members. Inclusion criteria: Both male and female persons with disabilities, aged 18 years and above, able to speak coherently, were included in the study. Exclusion criteria: Persons with disabilities aged less than 18 years and those who were not able to talk coherently were excluded from this study.

Questionnaire and face-to-face interviews were used for data collection. The questionnairewas originallywritten in English and translatedin Kinyarwanda. Questions were related tothe effect of strategic organizational structure on performance. The questionnaire comprised of four sections according to specific objectives of the study including: (a) Demographic characteristics of respondents; Effect of strategic organizational structure on growth; Effect of strategic organizational structure on effectiveness and; Effect of strategic organizational structure on innovativeness at the NCPD in Rwanda. The focus group methodology employed interview technique (Interview guide). Ten persons with disabilities were asked to interact, discuss and provide personal experiences. Therefore, focus group members discussed about the above-mentioned specific objectives of the study, and simultaneously, a tape recorder was used to collect group members' comments and personal experiences (Canals, 2017). 


\section{Research Findings and Discussion}

\begin{tabular}{|c|c|c|c|c|}
\hline \multirow{2}{*}{ Effect of structure on the NCPD's growth } & \multicolumn{2}{|c|}{ Agree } & \multicolumn{2}{|c|}{ Disagree } \\
\cline { 2 - 5 } & $\begin{array}{c}\text { Freq. } \\
(\mathrm{N}=138)\end{array}$ & $\begin{array}{c}\text { Percent } \\
(\%)\end{array}$ & $\begin{array}{c}\text { Freq. } \\
(\mathrm{N}=138)\end{array}$ & $\begin{array}{c}\text { Percent } \\
(\%)\end{array}$ \\
\hline Organic structure leads to greater productivity & 33 & 23.91 & 105 & 76.09 \\
\hline Structure improves greater utilization of resources & 23 & 16.67 & 115 & 83.33 \\
\hline $\begin{array}{c}\text { Sechanistic organisations are characterized by a rigid hierarchy; high levels of formalization; a } \\
\text { heavy reliance on rules, policies, and procedures slows organizational growth }\end{array}$ & 30 & 21.74 & 108 & 78.26 \\
\hline A good structure can lead to organizational effectiveness & 26.09 & 102 & 73.91 \\
\hline Grand Total & 35 & 25.36 & 103 & 74.64 \\
\hline
\end{tabular}

Table 1: Effect of Organizational Structure on the Performance of NCPD Source: Primary Data

Table1 shows that five questions were designed in the questionnaire to determine the effect of organizational structure on the NCPD's growth. Above findings of analyses based on cumulative answers disclose $533(77.25 \%$ ) respondents who disagreed and $22.75 \%$ of respondents who agreed that the structure has an effect on the organizational growth. The majority of respondents were in disagreementwith all assertions about the organizational growth, a major factor that resulted from the NCPD's structure. The effect of structure on growth was not significant because the organization could not expand, hire more employees, add more departments, or engage more departmental managers. There were no greater productivity, greater utilization of resources or increase of efficiency. These assertions are supported by Nwachukwu (2012) thatorganizational growth will be gauged by how well anorganization fulfils its overall goals and objectives. Similarly Barney (2011) holds up that, although having access to objective performance data of organizations is becoming difficult, and cautionary advice has been given when measuring performance of private organizations, especially when managers are not well disposed to revealing detailed accounting data of their organizations' performance. Therefore, efforts should be intensified to investigate what drives organization's performance within the organization context. As a result, subject measures of performance orselfreporting performance measures such as overallobjective fulfilment or overall perceived performance isadopted (Nandakumar et al., 2010). Growth is a vitalindicator of a flourishing organization. Some factors like characteristics of managers, access to resources like finance and manpower which affect the growth of the organization and differentiate it from a non-growing organization. Growth is a function of the decisions a manager makes like how to grow internally or externally and where to grow in domestic market or international market. An organization growth is related to size as well as other specific characteristics like financial structure and productivity. The gender of the founder, the amount the capital required at the time of starting the business and growth strategy of the organization are very important factors in predicting growth in an organization. Apart from human resources, growth can be predicted on the basis of commitment of the person starting a new organization (Gilbert et al.,2006).

\subsection{Regression Analysis}

\begin{tabular}{|c|c|c|c|c|}
\hline Model & R & R Square & $\begin{array}{c}\text { Adjusted R } \\
\text { Square }\end{array}$ & $\begin{array}{c}\text { Std. Error of } \\
\text { the Estimate }\end{array}$ \\
\hline 1 & $.802^{2}$ & 0.764 & 0.643 & 241 \\
\hline \multicolumn{4}{|c|}{ Predictors: (Constant), Structure of NCPD } \\
\hline a. Predictors: (Constant), Organization performance \\
\hline
\end{tabular}

Table 2: Model Summary

R-square is equal to $0.764(76.4 \%)$. This implies that $80.2 \%$ variations in organization structure have been captured by the model above, since the $\mathrm{p}$ value is 0000 , this means that Structure of NCPD influence the organization performance in NCPD.

The rule of Thumb is that, usually an $\mathrm{R}$ square of more than $50 \%$ is considered as better. This study proves the rule of Thumb the R2 is (76.4\%). In this study the rule of thumb is that, usually an $\mathrm{R}$ square of more than $50 \%$ is considered as better, this implyingthat District General Assembly structure has an impact on organization performance in NCPD.

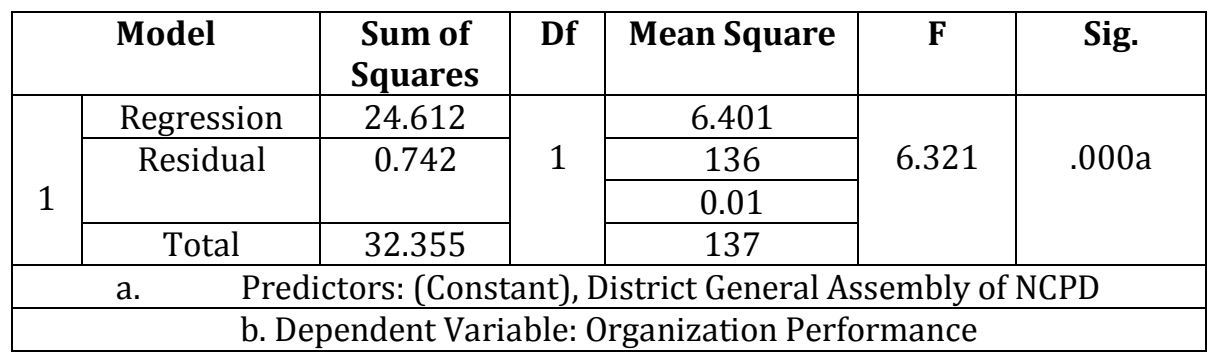

Table 3 


\begin{tabular}{|c|c|c|c|c|c|c|c|c|}
\hline & \multirow[b]{2}{*}{ Model } & \multicolumn{2}{|c|}{$\begin{array}{c}\text { Unstandardized } \\
\text { Coefficients }\end{array}$} & \multirow{2}{*}{$\begin{array}{c}\begin{array}{c}\text { Standardized } \\
\text { Coefficients }\end{array} \\
\text { Beta }\end{array}$} & \multirow[b]{2}{*}{$t$} & \multirow[b]{2}{*}{ Sig. } & \multicolumn{2}{|c|}{$\begin{array}{l}\text { 95.0\% Confidence } \\
\text { Interval for B }\end{array}$} \\
\hline & & B & $\begin{array}{l}\text { Std. } \\
\text { Error }\end{array}$ & & & & $\begin{array}{l}\text { Lower } \\
\text { Bound }\end{array}$ & $\begin{array}{l}\text { Upper } \\
\text { Bound }\end{array}$ \\
\hline 1 & (Constant) & 1.610 & .673 & & $\begin{array}{c}2.39 \\
1\end{array}$ & $\begin{array}{c}.01 \\
9\end{array}$ & .268 & 2.951 \\
\hline & $\begin{array}{c}\text { General Assembly of } \\
\text { NCPD }\end{array}$ & .832 & .078 & .802 & $\begin{array}{c}11.4 \\
84\end{array}$ & $\begin{array}{c}.00 \\
0\end{array}$ & .357 & .000 \\
\hline
\end{tabular}

Table 4: Coefficients ${ }^{a}$

The results indicate that NCPD Structure have a relationship with organization performance. The significance is 0.000 which indicates that there is positive relationship (0.832) between NCPD structure and NCPD performance. The beta of structure of NCPD is .832, which means that an unit change in NCPD structure leads to a 0.832 units increase in NCPD performance while keeping other variable constant.

\section{Conclusion}

It can be concluded that the performance of an organization largely depends on its structure. In other terms, organizational structure significantly affects organizational performance; it affects performance in its growth, effectiveness and innovativeness objectives. When a clear organizational structure exists, employees perform better, responsibilities are well-attributed and performance increases. Having a well-designed structure is a precondition for long-term performance.

\section{Recommendations}

This study recommends that management should critically analyse the effectiveness and efficiency of the organizational structure as an important predictor of performance. Proper structures should be put in place in order to achieve set goals and objectives. Further, non-performing organizations should redesign their structures in order to attain the expected performance.

\section{References}

i. Awino, Z.B. (2015). Organizational structure andperformance of large manufacturing firms in Kenya: An empirical investigation. Journal of Business and Economics, 6(11), 1883-1891

ii. Daft, R., Murphy, J. and Willmott, H. (2010). Organizational Theory and Design; United Kingdom: Thomas Rennie

iii. Gupta, M. (2015). Organizational structure affected by strategic change; international journal of advance research and innovative ideas in education; 1(3):2395- 4396

iv. Jones, G. (2013). Organizational Theory, Design, and Change (7th Ed.); England: Pearson, Harlow

v. Nedal, M.E., Ahmed E.O. \& Abdalla A.A. (2013). Defining and Solving the Organizational Structure Problems to Improve the Performance of Ministry of State for Environmental Affairs - Egypt; International Journal of Scientific and Research Publications, 3:10

vi. Olajide, O.T. (2015). Effects of Organizational Structure on Job Satisfaction in the Nigerian Financial Sector: Empirical Insight from Selected Banks in Lagos State. NG-Journal of Social Development, 5(1), 96-108

vii. Peersman, G. (2014). Overview: Data Collection and Analysis Methods in Impact Evaluation, Methodological Briefs: Impact Evaluation 10, UNICEF Office of Research, Florence

viii. Public ServiceCommission(2015). Guidelineson design of organization structures in the Public Service; Nairobi, Kenya.

ix. Ringim, K. J.,Razalli, M. R. and Hasnan, N. (2012). Moderating effect of Information Technology (IT) Capability on the Relationship between Business Process Reengineering Factors and Organizational Performance of Bank; African Journal of Business Management, 6(16), 5551-5567

x. Sablynski, C. J. 2012). Foundation of Organizational Structure; SL

xi. Teixeira, R., Koufteros, X. A. and Peng, X. D. (2012). Organizational Structure, Integration, andManufacturing Performance: A Conceptual Model and Propositions. Journal of Operations and Supply Chain Management, 5(1), 69-81 